\title{
CARACTERIZAÇÃO LITOLÓGICA E EVOLUÇÃO METAMÓRFICA DA PORÇÃO LESTE DO COMPLEXO METAMÓRFICO BRUSQUE, SANTA CATARINA
}

\author{
RUY PAULO PHILIPP', GUILHERME MALLMANN ${ }^{2}$, MARIA DE FÁTIMA BITENCOURT ${ }^{1}$, \\ EDUARDO RECKZIEGEL DE SOUZA², MARCOS M. A. DE SOUZA ${ }^{2}$, \\ JOAQUIM DANIEL DE LIZ ${ }^{2}$, FELIPE WILD ${ }^{2}$, SILVANA ARENDT ${ }^{2}$, ALESSANDRO S. DE \\ OLIVEIRA $^{2}$, LAUREN DUARTE ${ }^{2}$, CRISTIANE B. RIVERA ${ }^{2} \&$ MAURÍCIO PRADO $^{2}$
}

\begin{abstract}
LITHOLOGIC CHARACTERIZATION AND METAMORPHIC EVOLUTION OF THE EASTERN PORTION OF THE BRUSQUE METAMORPHIC COMPLEX, SANTA CATARINA The eastern portion of the Brusque Metamorphic Complex comprises dominantly metassedimentary rocks, with subordinate metavolcanics. Sheets of peraluminous leucogranites are concordantly intrusive in this sequence, as well as larger granitic bodies, as the Compra Tudo, Valsungana and Serra dos Macacos granitoids. Regional deformation and orogenic metamorphism are here interpreted as polyphase events of Neoproterozoic age associated to continental collision. A younger metamorphic event is related to heat transfer from granitic magmas and to the development of ductile shear zones. Protoliths are dominantly marine sediments probably deposited in rift systems evolving towards continental margin enviroments. No evidence of ancient oceanic crust is found. Turbidites are characterized by systematically alternate pelites, feldspathic sandstones and quartz sanstones, with minor amounts of limestone and marble. Massive metavolcanic rocks of tholeiitic affinity are interpreted as former subaqueous basalt flows. Minor occurrences of chemical exhalative interflows are found as banded iron formations. Metamorphic evolution is complex and intimately related to deformation events. $M_{1}$ e $M_{2}$ metamorphic events are related to low-pressure, regional orogenic metamorphism synchronous to the development of foliations $\mathrm{S}_{1}$ and $\mathrm{S}_{2}$. Both were formed during continental collision, which caused important tectonic interleaving of the volcano-sedimentary sequence. Temperature conditions range from those of the greenschist facies to lower amphibolite, marked by chlorite, biotite, garnet, andaluzite and cordierite zones. Metamorphic zoning pattern is complex, with repetition and incompatibility of zones due to tectonic interleaving. $M_{3}$ metamorphic event is related to the intrusion of syn-transcurrence $\left(D_{3}\right)$, Neoproterozoic Valsungana and Serra dos Macacos granites, which develop contact metamorphic aureoles containing pelitic and calc-silicate rocks formed under albite-epidote hornfels to pyroxene hornfels facies conditions. Mylonitic rocks formed under greenshist facies conditions are found along the Major Gercino and ItajaíPerimbó shear zones.
\end{abstract}

Keywords: Catarinense Shield, Brusque Metamorphic Complex, Stratigraphy, Metamorphic Petrology

Resumo A porção leste do Complexo Metamórfico Brusque é constituída por uma sequêencia de rochas predominantemente metassedimentares, com ocorrência subordinada de rochas metavulcânicas. Esta sequiência é intrudida por granitóides, representados por corpos tabulares e injeções de leucogranitos peraluminosos, e pelos granitos Compra Tudo, Valsungana e Serra dos Macacos. A deformação e o metamorfismo regional orogênico são interpretados neste trabalho como polifásicos e ocorreram no Neoproterozóico, associados a um processo de colisão continental. Um novo evento metamórfico está relacionado a transferência de calor por magmas graníticos e ao desenvolvimento de zonas de cisalhamento dúcteis. A sedimentação é dominantemente marinha e relacionada provavelmente a um sistema de rifis que evoluem para uma margem continental, sem registro de crosta oceânica. Ocorrem turbiditos, caracterizados pela alternância sistemática de pelitos, arenitos feldspáticos e quartzo-arenitos, e de modo subordinado calcáreos e margas. As rochas vulcânicas correspondem a derrames básicos subaquosos de afinidade toleítica, com estruturas maciças. Interfluxos exalativos químicos, tais como formações ferríferas bandadas, ocorrem de forma restrita. A evolução metamórfica é complexa e

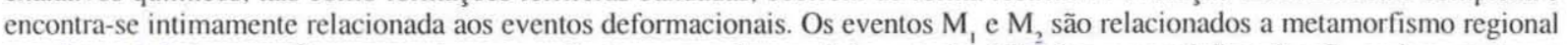
orogênico de baixa pressão, ocorrendo concomitantes com o desenvolvimento das foliações metamórficas $\mathrm{S}_{1}$ e $\mathrm{S}_{2}$, ambas estruturas geradas durante o evento colisional. Esta estruturação é responsável pela intercalação tectônica de fatias da sequiência vulcanosedimentar pretérita. As condições de temperatura evoluem da fácies xistos verdes a anfibolito inferior, e possuem um padrão de zonação complexo, com repetições e incongruëncias de zonas metamórficas, que variam desde a zona da clorita, passando para biotita, granada, andaluzita e cordierita. $\mathrm{O}$ evento $\mathrm{M}_{3}$ está associado ao posicionamento dos granitóides Brasilianos sintranscorrência $\left(\mathrm{D}_{3}\right)$ Valsungana e Serra dos Macacos, e desenvolve auréola de metamorfismo de contato, com cornubianitos pelíticos e calci-silicáticos, sob condições metamórficas da fácies albita-epidoto cornubianito a piroxênio cornubianito.

Palavras-chave: Escudo Catarinense, Complexo Metamórfico Brusque, Estratigrafia, Petrologia Metamórfica

1 - Centro de Estudos em Petrologia e Geoquímica - CPGq, Instituto de Geociências, UFRGS, Av. Bento Gonçalves, 9500, Caixa Postal 15001, Campus do Vale, Porto Alegre, RS, CEP: 91501-970. E-mail: ruy.philipp@ufrgs.br

2 - Programa de Pós-graduação em Geociências, UFRGS 
INTRODUÇÃo O Complexo Metamórfico Brusque (CMB), situado na porção leste do Escudo Catarinense, faz parte de uma das clássicas áreas de cinturões de dobramentos do sul do Brasil. Estende-se como uma faixa de direção NE-SW, com cerca de $75 \mathrm{~km}$ de extensão e largura máxima de 45 km (Fig. 1). Apresenta limites tectônicos, definidos a noroeste pela Zona de Transcorrência ItajaíPerimbó (Silva 1991) e a sudeste pela Zona de Cisalhamento Major Gercino (Bitencourt et al. 1989), ambas estruturas de alta deformação, com comportamento dúctil, disposição subvertical e movimentação transcorrente dextral. O CMB faz contato a noroeste com as seqüências vulcanossedimentares de cobertura tardi- a pós-brasilianas (Bacia do Itajaí), a norte com rochas paleoproterozóicas do Complexo Granulítico de Santa Catarina, e a sul e sudeste com rochas graníticas brasilianas. Na sua porção central, é intrudido por granitóides brasilianos. A relação de contato entre o $\mathrm{CMB}$ e as rochas gnáissico-migmatíticas do Complexo Camboriú são tectônicas, caracterizadas por uma zona de cisalhamento de empurrão que coloca em contato ambas as unidades a sul do Granito Itapema. As relações de contato entre o Granito Itapema e o CMB não apresentam evidências diretas de campo, entretanto, Bitencourt \& Nardi (2003) sugerem que o referido granitoé intrusivo no CMB. Esta indicação está relacionada a forma tabular do maciço granítico, a ocorrência de estruturas magmáticas suborizontais concordantes e pela presença de rochas do $\mathrm{CMB}$ a norte e a sul do corpo granítico.

O principal objetivo deste trabalho é apresentar novos dados estratigráficos, estruturais e metamórficos obtidos da integração dos levantamentos geológicos de detalhe e semidetalhe para a região compreendida entre as cidades de Itajaí e Tijucas, no estado de Santa Catarina. Os dados são referentes ao mapeamento geológico 1:25.000 da Folha Camboriú e parte sul da Folha Itajaí, desenvolvido pelos alunos e professores do Curso de Geologia da Universidade Federal do Rio Grande Sul (Projeto Camboriú UFRGS 2000). A descrição e interpretação de afloramentos e seções geológicas, levantamentos estruturais, associados ao estudo petrográfico, com ênfase petrológica e microestrutural, são as principais ferramentas utilizadas neste trabalho. Além da caracterização litológica, é apresentada discussão acerca da origem dos protólitos e caracterização paleoambiental, bem como da evolução das condições metamórficas.

\section{GEOLOGIA REGIONALECONTEXTOGEOTECTÔNICO O}

$\mathrm{CMB}$ representa uma das principais unidades do Escudo Catarinense, sendo objeto de estudos de diversos pesquisadores nas últimas décadas. Entretanto, as investigações estão restritas a mapeamentos de caráter regional, com raros trabalhos de detalhe associados a estudos científicos ou a levantamentos temporários relacionados a atividades mineradoras. Existe, portanto, grande carência de caracterização geoquímica, isotópica e geocronológica integradas a trabalhos de mapeamento geológico de semidetalhe. No presente trabalho, é adotada a designação Complexo Metamórfico Brusque (Silva \& Dias 1981, Silva 1991, Caldasso et al. 1995) em detrimento de Grupo Brusque (Schulz Jr. \& Albuquerque 1969, Basei 1985) tendo em vista as recomendações da Subcomissão de Nomenclatura Estratigráfica da IUGS (1994).

A evolução dos conceitos e concepções geotectônicas, associada ao aumento do número de pesquisas, resultou no enquadramento do $\mathrm{CMB}$ em diversos ambientes geotectônicos. Inicialmente, foi interpretado como uma associação de metassedimentos plataformais (Almeida 1967, Hasui et al. 1975). Correlação com ambiente de subducção foi sugerida por Trainini

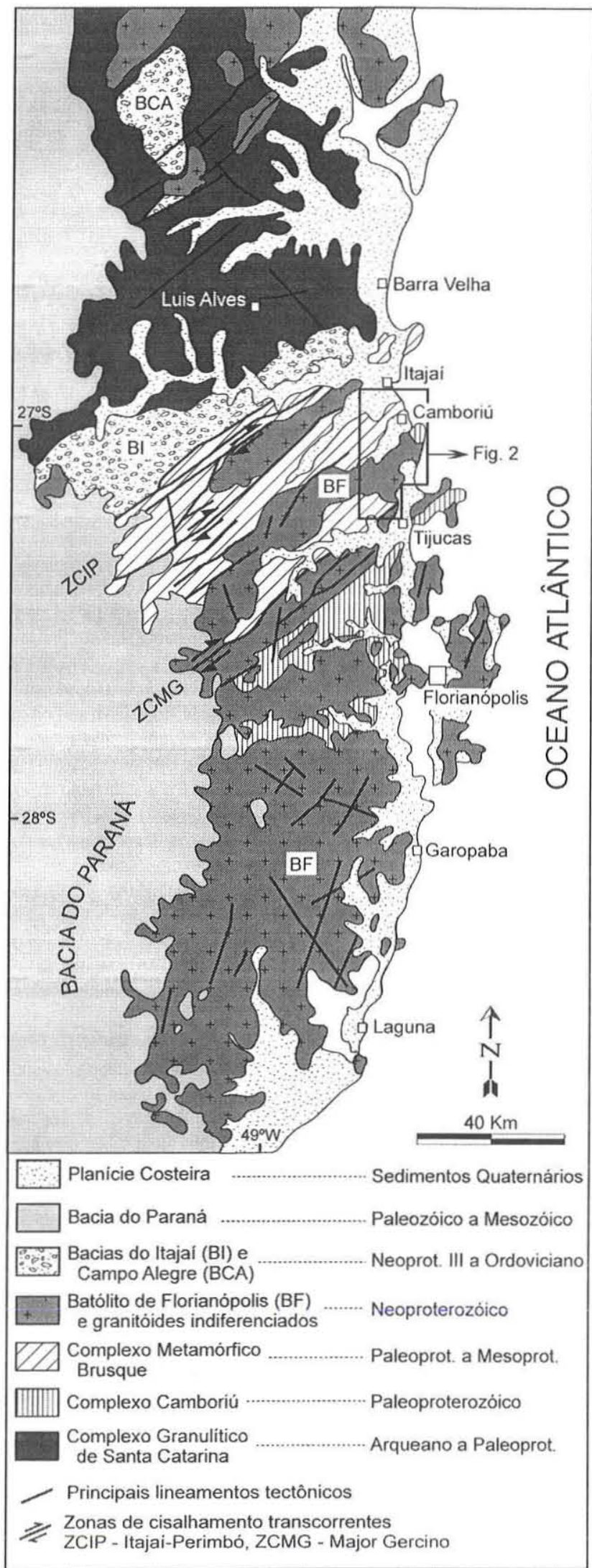

Figura I - Mapa geológico-geotectônico do Escudo Catarinense, com indicação da área de estudo (modificado de Hartmann \& Fernandes 2000). 
et al. (1978), que admitiam o CMB como uma associação gerada em arco insular. O reconhecimento de rochas metavulcânicas básicas e ultrabásicas intercaladas com os metassedimentos levou Silva \& Dias (1981), Silva (1983 a, b) e Silva et al. (1985) a considerar o CMB uma associação do tipo greenstone belt. Outra concepção visualizava no CMB uma associação de margem continental passiva associada com a evolução de um cinturão de dobramentos e/ou orogênico (Fragoso Cesar 1980; Basei 1985; Basei \& Teixeira 1987, Mantovani et al. 1987). Mais recentemente, Silva (1991) sugere que o CMB evoluiu em ambiente de rift.

Apesar da quantidade relativamente grande de determinações geocronológicas obtidas nas rochas do CMB por diversos autores, os intervalos de sedimentação e metamorfismo deste complexo ainda não estão bem estabelecidos, e resultados conflitantes não permitem estabelecer um quadro coerente da evolução temporal do Complexo. Os dados U-Pb SHRIMP obtidos por Hartmann et al. (2003) em zircões detríticos de quartzito do CMB indicam que a sedimentação da bacia é mais jovem que $2023 \pm 7 \mathrm{Ma}$. Um intervalo de 1500 a 2000 Ma para a sedimentação do CMB é sugerido por Basei (1990), com base em determinações U-Pb convencional em zircões detríticos de xistos pelíticos e rochas metavulcanossedimentares. O mesmo autor apresenta idade $\mathrm{Nd} \mathrm{T}_{\mathrm{DM}}$ de $1670 \mathrm{Ma}$ para rocha metavulcânica básica do Complexo, interpretando este valor como o mais antigo possível para a sedimentação do mesmo. O valor de $706 \mathrm{Ma}$. (Rb-Sr, rocha total), obtido por Basei \& Teixeira (1987) é interpretado por Basei (1990) como a idade mais representativa do clímax metamórfico do $\mathrm{CMB}$, correspondendo à segunda fase de metamorfismo $\left(\mathrm{M}_{2}\right)$ em paragnaisses. Por outro lado, Silva et al. (2002) referem idade magmática de $639 \pm 11 \mathrm{Ma}(\mathrm{U}-\mathrm{Pb}$ SHRIMP) obtida em zircões de metariolito, interpretado como registro de episódio vulcânico sindeposicional.

CARACTERIZAÇÃO LITOLÓGICA E ESTRUTURAL DO COMPLEXO METAMÓRFICO BRUSQUE Na área estudada, o CMB é constituído por uma associação metavulcano-sedimentar composta por filitos e xistos micáceos intercalados com semipelitos, quartzitos, rochas cálci-silicáticas, mármores, xistos magnesianos e metavulcânicas básicas. Na porção sul, é comum a ocorrência de corpos graníticos tabulares, com espessura de $1 \mathrm{~m}$, em média, variando entre $10-20 \mathrm{~cm} \mathrm{e} 3 \mathrm{~m}$, concordantes com a xistosidade principal. São leucossienogranitos peraluminosos, esbranquiçados a rosados.

Apesar da complexa estruturação tectônica do CMB, a superfí- cie de deposição original $\left(\mathrm{S}_{0}\right)$ é reconhecida com frequiência, principalmente por variações do tamanho de grão e da composição entre as camadas, permitindo o reconhecimento de seus protólitos. Por outro lado, a deformação e o metamorfismo não favorecem a adoção de unidades de fácies para subdividir os conjuntos litológicos, como anteriormente utilizado por Sander (1992) e Caldasso et al. (1995). A partir da integração dos dados de campo, subdividiu-se o $\mathrm{CMB}$ em cinco conjuntos litológicos com base nos protólitos dominantes, isto é, Subunidade Clástica - SC, Subunidade Química - SQ, Subunidade Clástico-Química - SCQ, Subunidade Metavulcânica Básica - SMB e Subunidade Magnesiana - SMg (Tabela 1). A Subunidade Clástica constitui ampla e espessa seqüência de metapelitos com intercalação subordinada de quartzitos puros e micáceos e raras lentes de metaconglomerado. Lentes e corpos irregulares de metamarga e mármore (SCQ e SQ) possuem contatos tectônicos ou gradacionais com esta subunidade. A ocorrência de rochas metavulcânicas é restrita (Fig. 2).

A evolução tectônica do CMB está relacionada a um evento dúctil tangencial $\left(\mathrm{D}_{1}-\mathrm{D}_{2}\right)$, cujo desenvolvimento progressivo é responsável pela geração da foliação metamórfica $\left(\mathrm{S}_{1}\right)$, preservada como dobras isoclinais a fechadas de flancos rompidos e charneiras espessas $\left(\mathrm{F}_{2}\right)$. A transposição desta foliação inicial gera a superfície $S_{2}$, em geral paralela a $S_{1}$, que constitui a xistosidade principal das rochas do CMB. A presença de zonas de alta deformação nos eventos deformacionais de baixo ângulo, marcadas pela transposição da foliação $S_{1}$ e geração de zonas de cisalhamento dúctil suborizontais, é indicativa da existência de intercalação tectônica de "fatias ou lascas" ao longo da evolução do cinturão. Estas estruturas foram afetadas por um evento transcorrente $\left(D_{3}\right)$, sob condições de deformação dúctil a dúctil-rúptil. As estruturas anteriores foram redobradas como dobras normais, fechadas a abertas $\left(\mathrm{F}_{3}\right)$, com clivagem de fratura de plano axial $\left(\mathrm{S}_{3}\right)$ orientada segundo a direção $\mathrm{N} 40-60^{\circ} \mathrm{E}$. Uma fase mais tardia de dobramentos é identificada pela presença de dobras $\mathrm{F}_{4} \mathrm{em}$ caixa, chevron e kink bands, abertas a suaves, com clivagem de fratura plano axial pouco espaçada, de direção $\mathrm{N} 40-70^{\circ} \mathrm{W}$. No contato com os granitos de idade neoproterozóica, há formação de cornubianitos, indicando metamorfismo de contato em condições variáveis entre as da fácies albita-epidoto cornubianito e piroxênio cornubianito. As rochas cornubianíticas freqüentemente apresentam estrutura xistosa ou acamadamento composicional parcialmente preservado, o que pode mascarar o metamorfismo termal a primeira vista. $\mathrm{O}$

Tabela I - Principais associações metamórficas e unidades litológicas do Complexo Metamórfico Brusque (UFRGS 2000).

\begin{tabular}{|c|c|c|c|}
\hline \multirow{2}{*}{ Seqüência } & \multirow{2}{*}{ Unidade } & \multicolumn{2}{|r|}{ Litofácies } \\
\hline & & Dominantes & Subordinadas \\
\hline \multirow{3}{*}{$\begin{array}{l}\text { Metassedimentar } \\
\text { Clástica }\end{array}$} & Pelítico-arenosa & Metaritmitos pelítico-arenosos & $\begin{array}{l}\text { Metaritmitos arenosos, metarenitos, } \\
\text { metapelitos e metapelitos carbonosos }\end{array}$ \\
\hline & Arenosa & Metaquartzo-arenitos & Metaquartzo-arenitos micáceos \\
\hline & Conglomerática & Metaconglomerados & Metaquartzo-arenitos e metaquartzo-arenitos micáceos \\
\hline $\begin{array}{l}\text { Metassedimentar } \\
\text { Clástico-química }\end{array}$ & Cálci-silicática & $\begin{array}{l}\text { Metamargas aluminosas e } \\
\text { alumino-silicosas }\end{array}$ & Grafita xistos \\
\hline $\begin{array}{l}\text { Metassedimentar } \\
\text { Química }\end{array}$ & Carbonática & $\begin{array}{l}\text { Metacalcáreos calcíticos e } \\
\text { dolomíticos }\end{array}$ & Metacalcáreos dolomíticos silicosos \\
\hline $\begin{array}{l}\text { Metavulcanogênica } \\
\text { Básica }\end{array}$ & $\begin{array}{l}\text { Vulcanogênica } \\
\text { Máfica }\end{array}$ & Derrames básicos & $\begin{array}{l}\text { Rochas cálci-silicáticas e quartzo turmalinitos } \\
\text { bandados, metassedimentos epiclásticos }\end{array}$ \\
\hline Magnesiana & $\begin{array}{l}\text { Vulcanogênica } \\
\text { Ultramáfica (?) }\end{array}$ & Derrames ultrabásicos (?) & \\
\hline
\end{tabular}




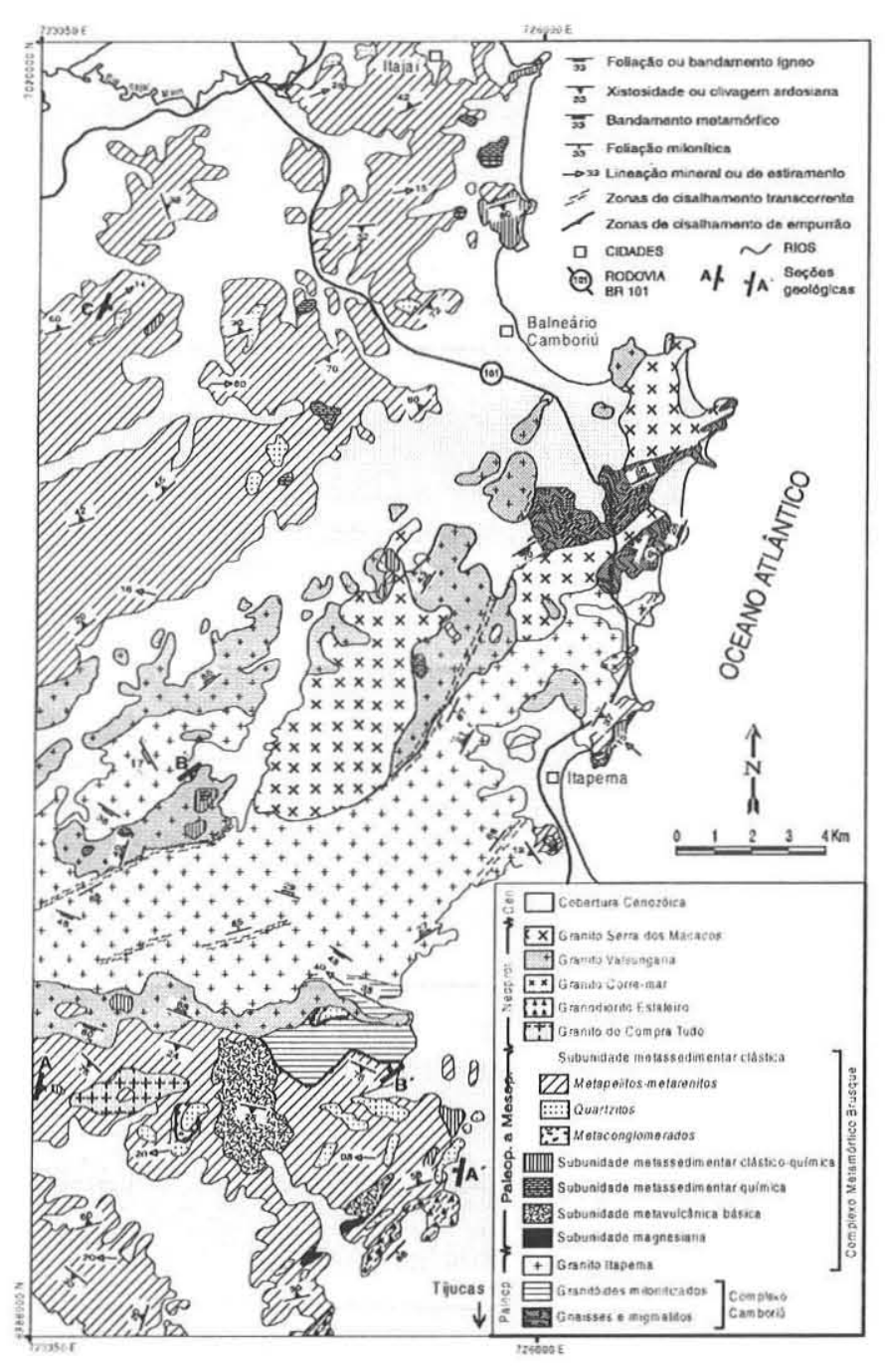

Figura 2 - Mapa geológico da região entre Itajaí e Tijucas, $e$ localização das seções da figura 3 (UFRGS 2000).

crescimento mineral sem orientação e as texturas minerais de reequilíbrio termal caracterizam as novas paragêneses de contato. As relações espaciais entre as associações litológicas do CMB e as unidades graníticas são ilustradas de forma simplificada na figura 3.

Subunidade Clástica A subunidade clástica compreende três conjuntos litológicos distintos, que são: metapelitos-metarenitos, quartzitos e metaconglomerados.

METAPELITOS-METARENITOS Estas rochas têm relativa homogeneidade composicional e são predominantes em relação às demais, ocorrendo em toda a área estudada. Compreendem xistos e filitos pelíticos, com intercalação de termos areno-pelíticos em proporções variadas. Os afloramentos são muito intemperizados, com exposições de rochas frescas localizadas preferencialmente nas drenagens. A rocha sã mostra cor cinza esverdeada clara e escura, adquirindo cor laranja avermelhada escura a amarronada quando alteradas. Entre os tipos principais ocorrem muscovita-clorita-quartzo xistos e filitos, muscovita-biotita-quartzo xistos e filitos, com ocorrências mais restritas de granada- muscovita-biotita-quartzo xistos. Intercalações de grafita xistos são raras. Andaluzita-biotita-muscovita xistos são identificados apenas na porção norte, a sul do Rio Itajaí-Mirim, enquanto cordierita-biotita-muscovita xistos se restringem ao extremo sul da cidade de Itapema. Neste local, são identificados os corpos leucograníticos de maior espescura entre 1,5 e $3 \mathrm{~m}$. A estrutura dominante é uma xistosidade bem desenvolvida, ocorrendo subordinadamente clivagem ardosiana, principalmente na porção norte do Complexo. Em áreas onde $\mathrm{S}_{\text {, }}$ está preservada, pode-se observar a formação de clivagem de crenulação $S_{2}$. A textura principal é lepidoblástica hipidioblástica média a grossa, ocorrendo nos níveis quartzosos textura granoblástica equigranular interlobada a poligonal. Nos filitos ainda pode ser observada textura blastopsamítica definida, nos níveis arenosos, por cristais de quartzo arredondados, subgrãos e extinção ondulante.

Intercalações composicionais milimétricas a decamétricas entre termos areno-pelíticos e pelíticos podem ser observadas em seções ao longo de drenagens. No interior de camadas arenosas, variações de tamanho de grão são observadas em lâmina delgada (Fig. 4e).

No limite sudoeste da área mapeada, foram identificados raros corpos tabulares de metaturmalinitos de cor escura, com espessura de 2 a $4 \mathrm{~m}$, concordantemente intercalados aos metapelitos. Sua estrutura interna é marcada pela alternância de níveis milimétricos, regulares e contínuos, de turmalina e quartzo. A orientação preferencial de prismas aciculares de schorlita marca sua textura nematoblástica.

QUARTZITOS Ocorrem intercalados com os metapelitos, constituindo lentes centimétricas a decamétricas, com espessura de 10 a $30 \mathrm{~m}$. A maior exposição desta unidade encontra-se no Morro da Caveira, a norte da cidade de Tijucas. Nesta ocorrência, a espessura média aflorante é de cerca de $200 \mathrm{~m}$. Outros corpos maiores ocorrem a sul da Serra da Miséria, a oeste da cidade de Itajaí (Fig. 4a) e próximo às cabeceiras do Rio do Meio.

Os quartzitos possuem cor branca amarelada e são dominantemente puros. Subordinadamente, ocorrem termos xistosos ricos em muscovita e minerais opacos. A estrutura principal é marcada pela foliação $S_{2}$; estruturas reliquiares compreendem variação granulométrica regular do quartzo ao longo de finas e contínuas bandas no interior das camadas, bem como intercalação de níveis ricos em mica branca e/ou minerais opacos.

\section{METACONGLOMERADOS As ocorrências de} metaconglomerados estão restritas ao Morro da Caveira, situando-se nas porções mais altas desta elevação. Encontram-se intercalados com quartzitos e muscovita quartzitos, em pacotes de 2 a $30 \mathrm{~m}$ de espessura. A rocha possui cor branca a rosa e estrutura orientada, marcada pela orientação preferencial do eixo maior de seixos estirados. Em zonas de baixa deformação, é possível ainda observar estratificação plano-paralela e acamadamento gradacional. A proporção de seixos em relação a matriz é em torno de $50 \%$, o que os caracteriza como conglomerados suportados pela matriz (Fig. 4b). Os seixos são de quartzito, mostrando seções circulares a elípticas, limites arredondados a subarredondados e diâmetros entre 5 e $20 \mathrm{~cm}$. Zonas de mais alta deformação são identificadas na base do pacote, marcadas pelo intenso estiramento dos seixos. A matriz é arenosa, composta por quartzo, com teor subordinado de minerais opacos e muscovita. A principal textura da matriz é granoblástica inequigranular poligonal a interlobada média, com presença subordinada de textura lepidoblástica média, 
A-A') SEÇÃO GEOLÓGICA RIO CAMPO NOVO - SERTÃO DO VALONGO

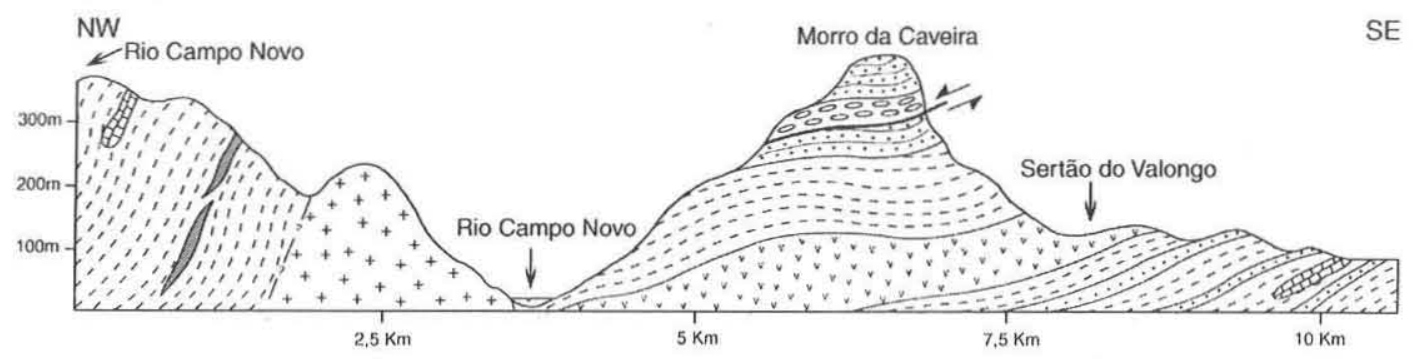

B-B') SEÇĀO GEOLÓGICA VILA DAS PEDRAS - SERRA DA MISÉRIA

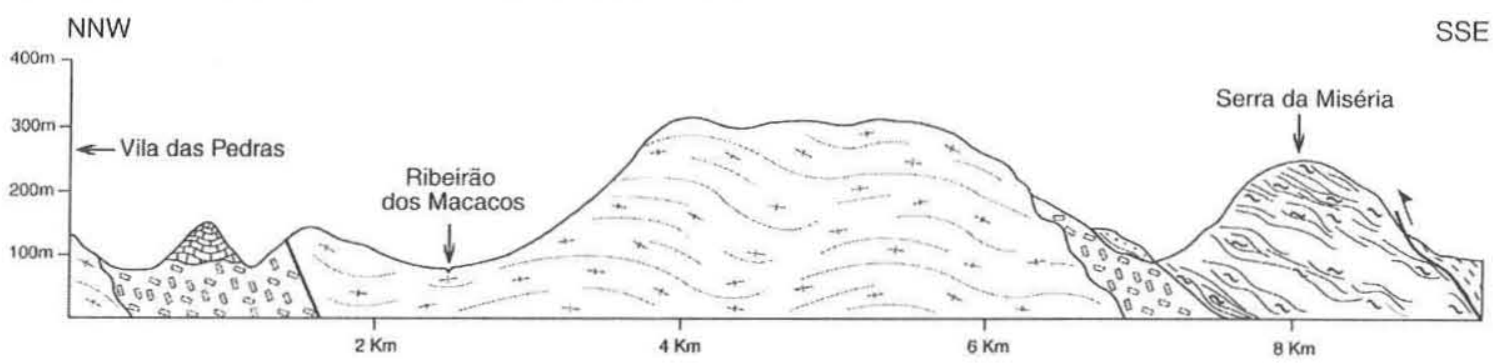

C-C') SEÇÃO GEOLÓGICA ARRAIAL DOS CUNHA - MORRO DO BOI

NW

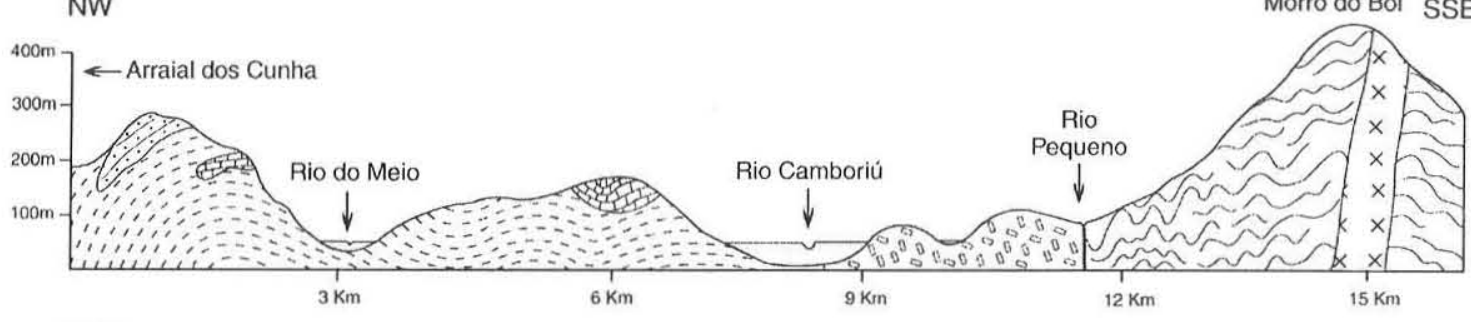

\begin{tabular}{|c|c|c|}
\hline & Sedimentos Cenozóicos & 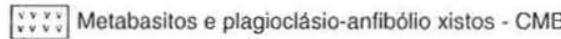 \\
\hline$x \times$ & Granito Serra dos Macacos & 28 Metaconglomerados - $\mathrm{CMB}$ \\
\hline & Granito Valsungana & $\begin{array}{l}\text { Mármores, rochas cálcio-silicatadas e } \\
\text { metamargas - CMB }\end{array}$ \\
\hline & Granito do Compra Tudo & XX Granito Itapema \\
\hline & Leucogranitos com turmalina - CMB & Granitóides milonitizados - Complexo Camboriú \\
\hline & $\begin{array}{l}\text { Xistos peliticos - CMB } \\
\text { Quartzitos - CMB }\end{array}$ & VN Gnaisses migmatiticos - Complexo Camboriú \\
\hline
\end{tabular}

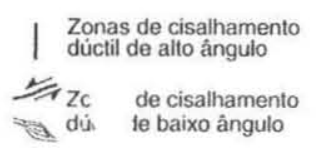

Figura 3 - Seções geológicas esquemáticas: A-A') Rio Campo Novo-Sertão do Valongo, B-B') Vila das Pedras-Serra da Miséria, CC') Arraial dos Cunha-Morro do Boi.

definida pela orientação de muscovita.

Subunidade Clástico-química Rochas de composição margosa foram descritas em pedreiras ativas de exploração de brita. Na porção norte e sul da área estudada, as metamargas ocorrem intercaladas com os metapelitos, enquanto na porção central constituem roof pendants nos granitos Valsungana e Serra dos Macacos, mostrando intenso registro de metamorfismo de contato.

As principais exposições ocorrem na Praia Brava (a leste de Itajaí) e no costão a norte da Praia de Itapema. Pequenas lentes boudinadas e alongadas segundo a direção NE-SW podem ser observadas na região do Sertão de Santa Luzia, a norte da cidade de Tijucas.

Dois tipos distintos de margas ocorrem nesta subunidade: (i) aluminosas e (ii) alumino-silicosas. O primeiro grupo compreende xistos de cor castanha escura, ricos em anfibólio e biotita, com teores baixos de minerais opacos, quartzo e epidoto. A textura principal é nematoblástica hipidiomórfica média a grossa, com textura lepidoblástica média a grossa subordinada. O segundo grupo é composto por rochas cálci-silicáticas de estrutura bandada a raramente xistosa. As bandas têm espessura milimétrica ( 1 a 20 $\mathrm{mm}$ ), grande regularidade e continuidade lateral (Fig. 4d) e resultam da alternância de níveis à base de diopsídio, grossulária, anfibólio e/ou biotita/flogopita com níveis ricos em plagioclásio, $\mathrm{K}$-feldspato, epidoto, quartzo e titanita. Apesar da forte superposição do metamorfismo termal, identifica-se ainda nestas litologias textura nematoblástica hipidiomórfica média a grossa e textura granoblástica equigranular interlobada média. Clorita, tremolita, clinozoizita, turmalina, apatita, mica branca, carbonato, magnetita e molibdenita estão associados principalmente ao 

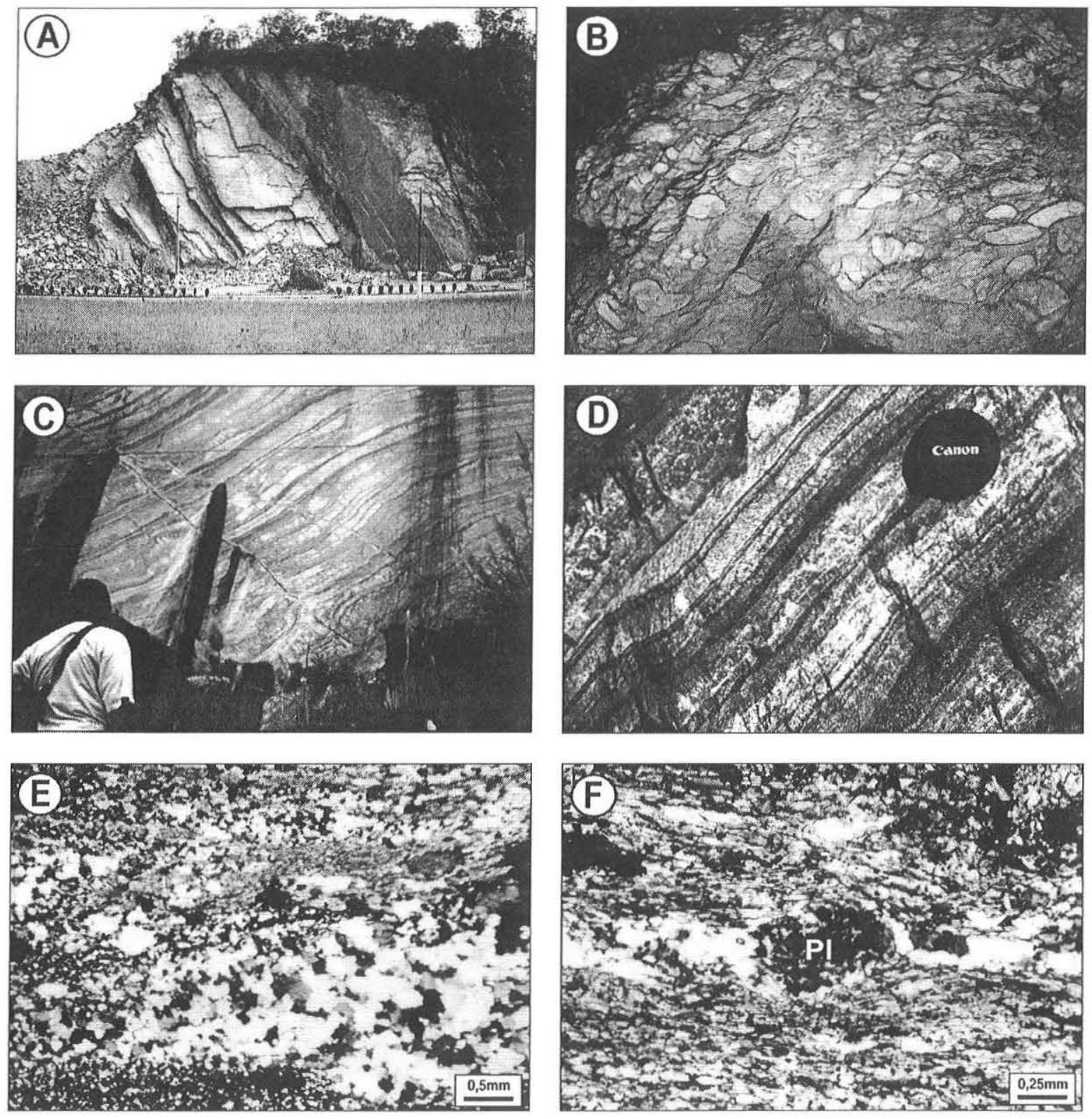

Figura 4 - Ilustração das estruturas primárias observadas no Complexo Metamórfico Brusque. A) Afloramento de quartzito na estrada de acesso a Itajai; B) Metaconglomerados do Morro da Caveira. Notar o estiramento dos seixos e o desenvolvimento de estruturas do tipo $S$-C; C) Mármore dolomítico silicoso com acamadamento sedimentar preservado (Pedreira a sudoeste de Camboriú); D) Bandamento composicional em rocha calci-silicática, com níveis máficos ricos em diopsídio e grossulária, níveis melanocráticos à base de epidoto, titanita, tremolita-actinolita, e níveis félsicos com plagioclásio, K-feldspato e quartzo (Pedreira da Votorantim, oeste da Serra dos Macacos); E) Magnetita-muscovita-quartzo xisto com acamadamento primário indicado pela alternância composicional e variação granulométrica, luz polarizada, 25x; F) Epidoto-plagioclásio-hornblenda xisto com fenocristal reliquiar de plagioclásio - Pl, luz polarizada, 50x (Costão a norte da Praia de Itapema).

metamorfismo de contato.

Subunidade Química As rochas metassedimentares químicas são descritas em antigas pedreiras de extração de blocos para rocha ornamental, e constituem mármores calcíticos a dolomíticos, com raras bandas de metapelitos e quartzitos. Intercalam-se às rochas clástico-químicas e clásticas na forma de lentes pouco alongadas na direção norte-sul, com maior comprimento aflorante entre 200 e 1000 metros, restritas à porção norte da área estudada. Estas rochas são encontradas também como roof pendants nos granitos Valsungana e Serra dos Macacos, mostrando, neste caso, intenso metamorfismo termal. Os mármores apresentam cores esbranquiçadas a alaranjadas e estrutura primária definida por um bandamento centimétrico a milimétrico, regular e contínuo, alternando níveis ricos em carbonato com níveis muito estreitos, ricos em micas ou anfibólio (Fig. 4c). A principal textura é granoblástica 
poligonal média a grossa. Flogopita-clorita mármores têm ocorrência subordinada; apresentam bandamento composicional milimétrico a decamétrico, definido pela intercalação de camadas quase contínuas de quartzo e calcita com bandas ricas em flogopita e clorita. Ocasionalmente, contêm lentes puras, de cor branca, compostas por mármores calcíticos e/ou calcítico-dolomíticos.

Subunidade Metavulcânica Básica Rochas desta subunidade, ocorrem apenas na porção sul da área estudada, aflorando como corpos concordantes, intercalados nos metapelitos. A principal exposição está localizada no Sertão do Valongo, a norte da cidade de Tijucas, constituindo um pacote suborizontal com aproximadamente 150 a 200 m de espessura. Nas ocorrências menores, localizadas a sudeste da principal, são observadas espessuras de cerca de $30 \mathrm{~m}$ e estreitas intercalações de xistos magnesianos. Pequenas exposições também ocorrem no costão, a norte da Praia de Itapema, intercaladas com xistos magnesianos, metamargas e metapelitos.

Os metabasitos são anfibólio xistos de cor verde escura a preta, com estrutura planar marcada pela orientação dimensional de prismas de anfibólio. A mineralogia é composta por albita, actinolita, epidoto e clorita, com presença subordinada de plagioclásio cálcico, hornblenda e quartzo. A principal textura metamórfica é a nematoblástica hipidiomórfica média a grossa, definida por prismas orientados de actinolita e hornblenda. Nos espaços intersticiais, plagioclásio, epidoto e minerais opacos mostram textura granoblástica inequigranular interlobada fina a média.Um protólito de natureza vulcânica é definido pela presença de textura blastoporfirítica, caracterizada por porfiroclastos de plagioclásio cálcico com formas prismáticas euédricas a subédricas e dimensões entre 1 e $3 \mathrm{~mm}$ (Fig. 4f). Ocasionalmente, observa-se textura blastoamigdaloidal, caracterizada pela presença de agregados de quartzo com formas arredondadas e dimensões entre 1 e $4 \mathrm{~mm}$.

Subunidade Magnesiana As rochas ultramáficas constituem corpos tabulares de extensão métrica a decamétrica e espessura de $25 \mathrm{~cm}$ até $4 \mathrm{~m}$, concordantes com a foliação principal. Sua identificação é restrita à porção sul da área estudada, onde se intercalam com metapelitos e metabasitos. As rochas desta subunidade são tremolita xistos, com ocorrência subordinada de tremolitaactinolita xistos. Nos tremolita xistos ocorrem também clinocloro, talco e magnetita, enquando nos actinolita xistos ocorrem subordinadamente penina e minerais opacos. Ambos os xistos possuem cor esverdeada clara, adquirindo tonalidades alaranjadas ou avermelhadas quando alterados. A estrutura principal é xistosa e a textura dominante é nematoblástica média a grossa.

INTRUSÕES GRANÍTICAS No CMB ocorrem diversas intrusões graníticas, cujas relações temporais e estruturais indicam a geração de dois grandes eventos de magmatismo granítico distintos. O primeiro evento está associado com a evolução metamórfica do complexo, caracterizado por corpos leucosienograníticos com formas tabulares e posicionamento vinculado à evolução da xistosidade principal $\left(\mathrm{S}_{2}\right)$ de disposição suborizontal, que marca a segunda fase de metamorfismo regional orogênico ( $\left.\mathrm{M}_{2}\right)$ (Fig. 5). O segundo magmatismo granítico é mais tardio, e apresenta uma colocação relacionada à evolução das zonas de cisalhamento dúcteis transcorrentes. Os corpos leucosienograníticos são peraluminosos e possuem espessuras centimétricas a métricas. Mostram cor esbranquiçada a rosada, estrutura maciça ou foliada e textura equigranular hipidiomórfica média, contendo proporções variáveis de moscovita e/ou biotita,

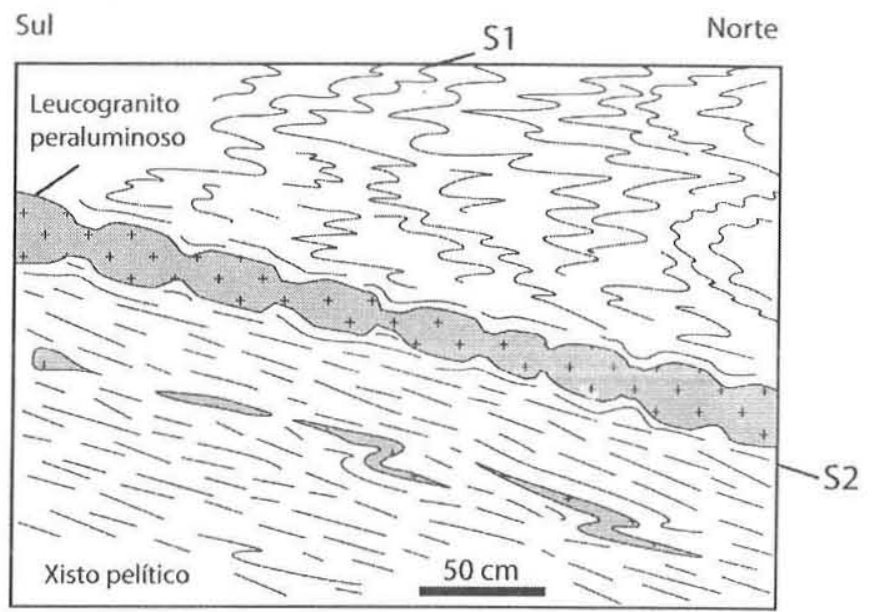

Figura 5 - Croqui geral indicando as relações de posicionamento dos corpos leucograníticos peraluminosos (sin $\mathrm{S}_{2}$ ), costão da praia da Ponta Grossa, norte de Itapema.

por vezes acompanhadas por turmalina e granada. As intrusões são freqüentemente boudinadas e sua estrutura interna é marcada por uma foliação de fluxo paralela aos limites da intrusão, raramente acompanhada por deformação de estado sólido concordante, caracterizada pelo estiramento dos grãos de quartzo, cristalização de mica branca e epidoto sobre feldspatos e recuperação parcial de quartzo e K-feldspato.

A intrusão dos Granitos Valsungana e Serra dos Macacos está associada com a evolução das zonas de cisalhamento de alto ângulo Major Gercino e Itajaí-Perimbó. Os corpos graníticos são alongados segundo NE-SW, paralelos as estruturas regionais subverticais (Figs. 2 e 3). O Granito Valsungana apresenta composição monzogranítica e textura porfirítica caracterizada por megacristais de $\mathrm{K}$-feldspato imersos em matriz equigranular grossa. A estrutura magmática é concordante, definida pelo alinhamento de megacristais de K-feldspato e biotita, subordinadamente, pelo alongamento do quartzo. O Granito Serra dos Macacos é constituído por três corpos com forma alongada orientada segundo NE-SW, concordante com as estruturas regionais. Possui composição sienogranítica, textura equigranular média e estrutura maciça, localmente com orientação primária de biotita. Ambos granitos mostram relações estruturais caracterizadas por uma colocação posterior ao desenvolvimento da foliação metamórfica principal $\left(\mathrm{S}_{2}\right)$. O posicionamento destas unidades é responsável pela formação de rochas cornubianíticas, gerando auréolas de contato que podem ser observadas nas proximidades dos plútons graníticos, nas porções norte e sul da área estudada (Fig. 6). As auréolas apresentam extensão média de $1,5 \mathrm{~km}$, podendo atingir até $4 \mathrm{~km}$. Este evento termal gerou cornubianitos em condições metamórficas variáveis entre a fácies albita-epidoto cornubianito e a fácies piroxênio cornubianito. Associados com este evento termal ainda ocorrem transformações metamórficas relacionadas ao desenvolvimento das zonas de cisalhamento dúcteis que limitam o CMB. Registros deste tipo de metamorfismo estão preservados pelo desenvolvimento de faixas de rochas miloníticas na porção noroeste e sudeste do Granito Valsungana, nos gnaisses do Complexo Camboriú, bem como, na região de Tijucas, em granitóides correlacionados com os granitos Estaleiro e Zimbros de Bitencourt et al. (1993) e UFRGS (2000). 


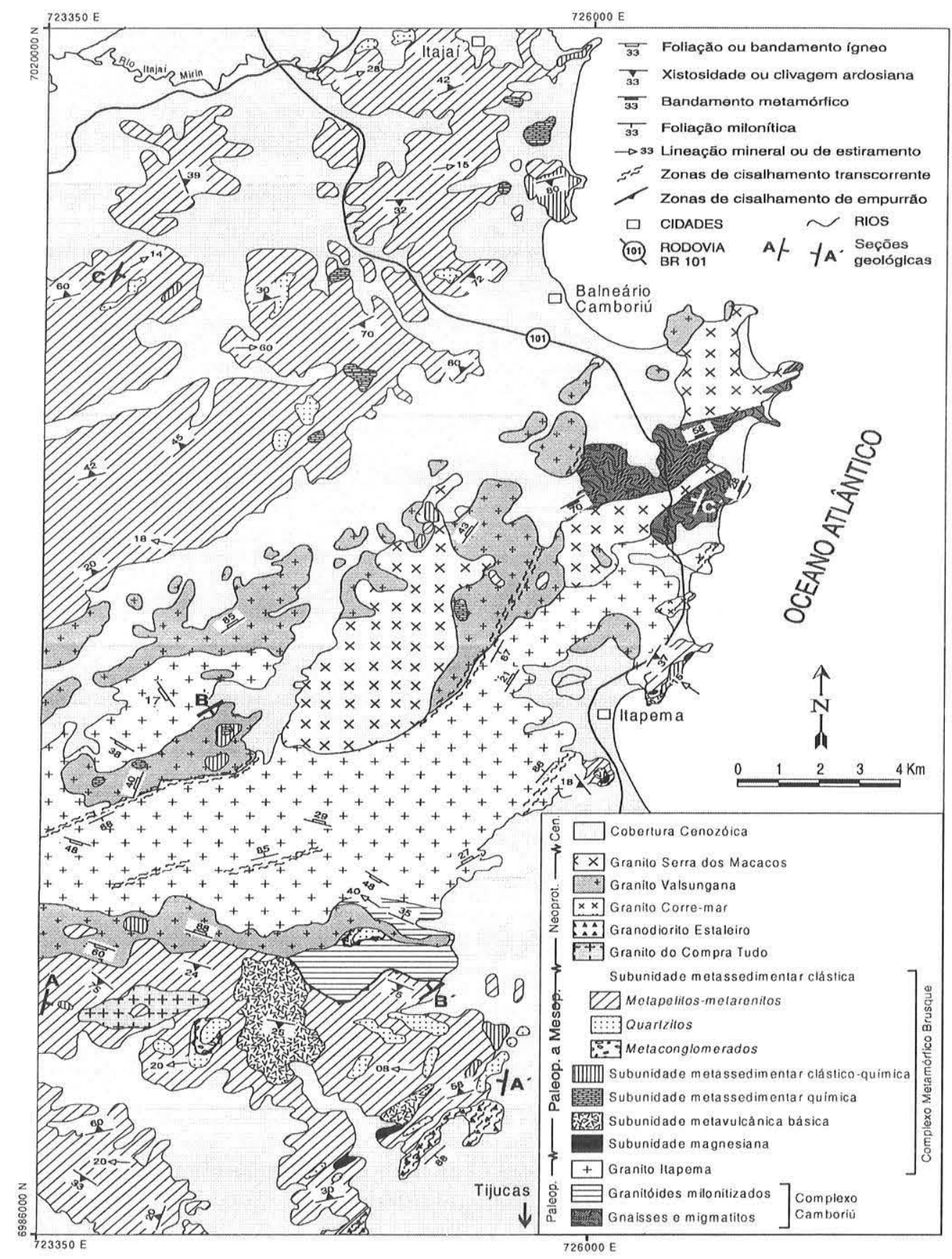

Figura 6 - Mapa metamórfico do Complexo Metamórfico Brusque entre Itajaí e Tijucas ilustrando as principais zonas e paragêneses do metamorfismo regional orogênico, paragêneses e áreas afetadas por metamorfismo de contato e locais com metamorfismo de zona de cisalhamento.

PALEOAMBIENTES A ocorrência comum de estruturas e texturas reliquiares nas litologias do $\mathrm{CMB}$ propicia adequada caracterização dos protólitos. O CMB mostra associações distintas de litótipos na porção norte e sul da área estudada. Ao norte, o complexo é composto por metassedimentos dominantemente pelíticos, com ocorrência significativa de metamargas e mármores, e presença subordinada de camadas arenosas e quartzíticas. Na porção sul, predominam ritmitos, com ampla ocorrência de quartzitos e camadas de metaconglomerados. Destacam-se nesta região a in- tercalação dos metassedimentos com rochas metavulcânicas básicas, corpos concordantes de ultramafitos e a presença localizada de turmalinitos. A ocorrência de camadas de meconglomerados suportados por matriz, intercaladas às rochas quartzíticas, e a presença exclusiva de seixos de quartzitos indica movimentos tectônicos no interior da bacia, com soerguimento e erosão dos pacotes arenosos. A presença de seixos e de matriz de composição essencialmente arenosa e rica em quartzo é sugestiva de conglomerados intraformacionais. 
As rochas das subunidades metassedimentares apresentam relações de contato gradacionais, marcadas pela alternância composicional sistemática entre metapelitos, quartzitos, metamargas e mármores. Os metassedimentos clásticos são dominados por expressivo pacote contendo ritmitos pelíticos e arenopelíticos, sugerindo deposição por correntes de turbidez de baixa densidade. Os metassedimentos preservam estrutura plano-paralela caracterizada pelo acamadamento composicional de espessura milimétrica a centimétrica com grande regularidade e continuidade, acompanhado por variações sistemáticas e regulares do tamanho de grão em níveis arenosos. Em lâmina delgada, é freqüente a identificação de texturas blastopsamíticas em filitos, xistos e quartzitos micáceos. Nos mármores, observa-se alternância composicional com camadas de rochas calci-silicáticas, mármores dolomíticos silicosos, dolomíticos e calcíticos.

Nos filitos e xistos, a presença de mineralogia metamórfica de composição aluminosa, como granada, andaluzita, cordierita, estaurolita e silimanita, acompanhada por teores elevados de clorita, muscovita e biotita, é indicativa de transformações metamórficas de rochas pelíticas. Do mesmo modo, a intercalação entre mármores e rochas calci-silicáticas indica a ocorrência de calcáreos e margas. A presença de grandes lentes de quartzitos atesta a ocorrência de corpos arenosos ricos em quartzo.

Os metassedimentos pelíticos, pelítico-arenosos e arenosos, bem como os mármores e rochas calci-silicáticas, caracterizam uma sedimentação com ampla contribuição continental, onde os metarritmitos representam os depósitos mais distais, associados a turbiditos de leques submarinos. Os conglomerados associados aos corpos quartzo-arenosos podem ter sua deposição associada com movimentações tectônicas durante a evolução da bacia. Os sedimentos arenosos ricos em quartzo não apresentam estruturas primárias diagnósticas. Entretanto, a presença de marcas onduladas nos quartzitos do Morro da Caveira, associada à espessura significativa do pacote arenoso nesta região, pode sugerir deposição associada a ambientes plataformais. Sander (1992) sugeriu para a formação dos corpos de quartzitos outras possibilidades, como cordões litorâneos, barras de costa afora ou turbiditos.

A ausência de estruturas primárias nos mármores não permitiu a caracterização de seu ambiente de formação. Entretanto, a ocorrência de metamargas laminadas intercaladas a metassedimentos pelíticos e areno-pelíticos, é sugestiva de que as mesmas tiveram evolução relacionada a depósitos turbidíticos. Na região de Botuverá (50 km a oeste da área estudada), a descrição de estruturas estromatolíticas de ambientes calmos de supra a intermarés, calcários oolíticos de ambientes de alta energia e calcários laminados relacionados a depósitos turbidíticos conduziu à interpretação da existência de uma plataforma carbonática no CMB (Sander 1992, Caldasso et al. 1995).

As rochas metabásicas ocorrem como corpos tabulares e apresentam grande homogeneidade composicional. Apesar da intensa recristalização metamórfica e da estrutura xistosa, ainda mostram texturas blastoporfiríticas e blastoamigdaloidais. A grande homogeneidade composicional e textural, associada à presença de texturas reliquiares (Silva 1991 Sander 1992) são características relacionadas a derrames básicos subaquosos. A presença de rochas ultrabásicas está restrita às ocorrências de xistos magnesianos. A associação dos metaultramafitos com os metabasitos, bem como a intercalação destes litótipos com metassedimentos pelíticos a pelítico-arenosos é indicativa de que este evento vulcânico ocorreu em condições distais com relação à área de costa.
Nos limites dos corpos de metabasitos, é possível reconhecer rochas básicas acamadadas. Na região a norte de Itapema, este acamamento pode apresentar intercalação de níveis máficos contínuos e regulares de espessura milimétrica compostos por anfibólio e flogopita, com níveis mais félsicos à base de epidoto, plagioclásio, minerais opacos e presença variável de diopsídio. Em xenólitos de rochas calci-silicáticas encontrados no interior do Granito Valsungana, o acamadamento é composto por níveis félsicos ricos em diopsídio, epidoto, cliozoizita e plagioclásio, e níveis máficos contendo hornblenda, tremolita, grossulária, titanita, apatita e, por vezes, flogopita. Estas variações composicionais são interpretadas como relacionadas a camadas margosas resultantes da combinação em proporções distintas de pelitos, lama carbonática e areia quartzosa. Entretanto, outros autores como Silva et al. (1983a, b, 1985) e Silva (1991), interpretam estes litótipos como associações metavulcânicas piroclásticas e metatufíticas (metatufos bandados, brechas de composição máfico-ultramáfica).

A ausência de rochas efusivas de composição andesítica ou toleítica de baixo $\mathrm{K}$, de rochas plutônicas cálcico-alcalinas do tipo cordilheirano, de associações metamórficas da fácies xistos azuis e de melanges tectônicas restringem a comparação com arcos insulares ou de margem continental ativa, como anteriormente salientado por Trainini et al. (1978) e Silva (1991). Estudos litogeoquímicos realizados por Sander (1992) em rochas metavulcânicas de composição básica encontradas na região de Botuverá indicaram uma composição química transicional entre toleítica e alcalina, compatível com ambiente vulcânico intraplaca, com magmatismo gerado no manto e sem contaminação crustal. Silva (1991) descreve a ocorrência de rochas metavulcânicas ácidas de composição alcalina (metatufos félsicos e metariodacitos) ao longo do Rio do Oliveira, região do Valongo.

A geometria da foliação principal, com direção dominantemente EW e baixo mergulho, aliada à ocorrência de dobras recumbentes e zonas de cisalhamento suborizontais, reflete uma intensa tectônica colisional, a qual é caracterizada inicialmente pelo encurtamento crustal associado ao desenvolvimento de estruturas de empurrão $\left(\mathrm{D}_{1}-\mathrm{D}_{2}\right)$. A geração de zonas de cisalhamento transcorrentes de escala litosférica $\left(\mathrm{D}_{3}\right)$ é provavelmente a responsável pela atual forma alongada do cinturão na direção NE-SW, adquirida no estágio pós-colisional do Ciclo Brasiliano.

EVOLUÇÃO METAMÓRFICA A evolução das condições metamórficas do CMB foi abordada anteriormente nos trabalhos de Silva et al. (1978, 1980), Basei (1985), Silva (1991), Sander (1992) e Caldasso et al. (1995). As principais conclusões dos estudos desenvolvidos neste trabalho contrastam em parte com as considerações apresentadas anteriormente.

$\mathrm{Na}$ área estudada, foi identificada a superposição de três tipos distintos de metamorfismo, que correspondem inicialmente a transformações vinculadas a metamorfismo regional orogênico $\left(M_{1}\right.$ e $\mathrm{M}_{2}$ ), seguida por evento termal relacionado à intrusão de rochas graníticas no fim do Neoproterozóico. Um último evento, identificado de modo mais restrito, está relacionado ao desenvolvimento de zonas de cisalhamento dúctil associadas ao posicionamento dos granitos sin- a tardi-transcorrência (Tabela 2). Esta superposição dificulta o estudo da evolução metamórfica do CMB, principalmente, pelo crescimento pronunciado de paragêneses metamórficas relacionadas ao metamorfismo de contato, que mascaram o equilíbrio mineral obtido no metamorfismo regional. $\mathrm{O}$ crescimento de fases minerais semelhantes em eventos de natureza distinta é outro ponto que causa significativas confusões na 
Tabela 2 - Principais tipos litológicos gerados pelo metamorfismo regional orogênico e pelo metamorfismo de contato no Complexo Metamórfico Brusque (UFRGS 2000).

\begin{tabular}{|c|c|c|c|}
\hline \multirow{2}{*}{$\begin{array}{l}\text { SEQÜÊNCIA } \\
\text { PRÉ- } \\
\text { METAMÓR. } \\
\text { FICA }\end{array}$} & \multirow{2}{*}{$\begin{array}{l}\text { UNIDA DE } \\
\text { DE } \\
\text { FÁCIES }\end{array}$} & \multicolumn{2}{|c|}{ TIPO LITOLÓGICO } \\
\hline & & Metamorfismo Regional Orogênico & Metamorfismo de Contato \\
\hline \multirow{3}{*}{$\begin{array}{l}\text { Metassedimentar } \\
\text { Clástical }\end{array}$} & Pelítico-arenosa & $\begin{array}{c}\text { Xistos e filitos micáceos com Clo. Bt. } \\
\text { Musc e, localmente Gran. And e } \\
\text { Cord. Níveis centimétricos de } \\
\text { quartzitos e raras lentes de grafita- } \\
\text { xistos }\end{array}$ & $\begin{array}{c}\text { Cornubianitos maciços com Bt, Musc, } \\
\text { Gran, Cian, And, Stt, Cord e Silim. } \\
\text { e rochas parcialmente xistosas a } \\
\text { bandadas com porfiroblástos pós. } \\
\text { cinemáticos }\end{array}$ \\
\hline & Arenosia & $\begin{array}{c}\text { Quartzitos puros com intercalações } \\
\text { centimétricas de quartzitos } \\
\text { micáceos, muscovita-quartzo xistos } \\
\text { e xistos micáceos }\end{array}$ & $\begin{array}{c}\text { Muscovita-quartzo cornubianitos e } \\
\text { quartzo cornubianitos }\end{array}$ \\
\hline & Conglomerática & $\begin{array}{c}\text { Meta-ortoconglomerados de matriz } \\
\text { arenosa com seixos } \\
\text { subarredondados de quartzitos } \\
\text { puros, intercalados na unidade } \\
\text { arenosa }\end{array}$ & Sem evidências \\
\hline $\begin{array}{l}\text { Metassedimentar } \\
\text { Clástico-química }\end{array}$ & $\begin{array}{l}\text { Rochas Cálci- } \\
\text { silicáticas }\end{array}$ & $\begin{array}{c}\text { Cálci-xistos com estrutura bandada e } \\
\text { teores variáveis de Carb, Flog, Act, } \\
\text { Trem, Epid e Plag, ocorrência } \\
\text { localizada de grafita-xistos }\end{array}$ & $\begin{array}{c}\text { Rochas cálci-silicáticas com estrutura } \\
\text { reliquiar bandada, textura } \\
\text { granoblástica grossa composta por } \\
\text { Carb. Ep, Clinoz, Plag, Gross. } \\
\text { Diop, Trem, FK, Esf, Apa }\end{array}$ \\
\hline $\begin{array}{l}\text { Metassedimentar } \\
\text { Química }\end{array}$ & Carbonática & $\begin{array}{c}\text { Mármores calcíticos com ocorrência } \\
\text { subordinada de mármores } \\
\text { dolomíticos silicosos e cálci-xistos } \\
\text { com anfibolio }\end{array}$ & $\begin{array}{l}\text { Mármores calcíticos maciços, } \\
\text { subordinadamente dolomíticos } \\
\text { silicosos com Carb, Wo. Titanita }\end{array}$ \\
\hline $\begin{array}{c}\text { Metavulca- } \\
\text { nogênica Básica }\end{array}$ & $\begin{array}{l}\text { Vulcanogê- } \\
\text { nica máfica }\end{array}$ & $\begin{array}{l}\text { Anfibólio xistos homogêneos, } \\
\text { ocorrência sobordinada de } \\
\text { anfibolitos bandados com níveis } \\
\text { centimétricos de anfibolitos } \\
\text { maciçose de Bt-Anf xistos }\end{array}$ & $\begin{array}{l}\text { Cornubianitos básicos ricos em } \\
\text { anfibolio, com teores subordinados } \\
\text { de Plag, Ep, Clo, Cumm. }\end{array}$ \\
\hline Magnesiana & $\begin{array}{l}\text { Vulcanogênica } \\
\text { ultramáfica }\end{array}$ & $\begin{array}{l}\text { Tremolita xistos e clorita-tremolita } \\
\text { xistos }\end{array}$ & Tremolititos e clorita-tremolititos \\
\hline
\end{tabular}

análise petrográfica.

As paragêneses associadas às foliações $S_{1}$ e $S_{2}$ (Figs. 7a,b) são características de evento metamórfico regional do tipo orogênico $\left(\mathrm{M}_{2}\right)$, gerado em condições metamórficas que variam da fácies xistos verdes, zona da clorita, passando pela zona da biotita, granada e andaluzita, atingindo, de modo localizado, a fácies anfibolito inferior, na zona da cordierita (Fig. 6, Tabela 3). O padrão de zonação metamórfica obtido para o metamorfismo orogênico foi reconstituído a partir de dados de campo e petrográficos, caracterizando-se por disposição subparalela das zonas em relação à xistosidade principal, com repetição de zonas de baixa temperatura no interior de zonas de temperatura mais alta.

A disposição espacial das zonas de metamorfismo regional apresentada neste trabalho aponta para a intercalação tectônica de fatias da seqüência metamórfica, e contrasta com aquelas indicadas por Silva et al. (1978, 1980), Basei (1985) e Silva (1991), que vincularam o aumento progressivo de temperatura aos granitóides da Suíte Valsungana.

O metamorfismo regional orogênico que afetou o CMB está relacionado ao Ciclo Brasiliano como indicado pelas idades geocronológicas do metamorfismo (Basei, 1985, Basei et al. 1987). As estruturas deformacionais e paragêneses encontradas nas rochas do CMB são indicativas do desenvolvimento de evento de metamorfismo regional orogênico em condições de fácies xistos verdes inferior a anfibolito inferior e baixa P/T. Este evento metamórfico está relacionado ao fechamento da bacia por um processo de colisão continental (tectônica de baixo ângulo) responsável pela formação da foliação $\mathrm{S}_{2}$, por uma lineação mineral e/ou de estiramento, disposta segundo a direção E-W, dobras recumbentes e zonas de cisalhamento paralelas a $\mathrm{S}_{2}$. A evolução metamórfica está registrada na foliação $S_{2}$ e pelas relações temporais de crescimento dos porfiroblastos de andaluzita, granada e cordierita nas rochas metapelíticas.

O desenvolvimento de cordierita em porfiroblastos $\sin -\mathrm{S}_{2}$ indica que a geração desta foliação está associada ao aumento da espessura do pacote de metassedimentos relacionado à formação das dobras $\mathrm{F}_{2}$ (recumbentes) e promovido pela defor-mação tangencial. $\mathrm{O}$ aparecimento de cordierita nos metapelitos e de hornblenda + plagioclásio cálcico nos metabasitos coincide com o aparecimento sistemático de corpos tabulares de leucograni-tos peraluminosos. Estes corpos mostram-se concordantes com $\mathrm{S}_{2}$ e estão afetados por esta fase deformacional, com boudi-nage,orientação e estiramento mineral. A presença de andaluzita e cordierita em um cinturão de natureza colisional poderia ser explicada pelo rápido soterramento associado com o aumento progressivo da temperatura, que atingiria condições compatíveis com a fusão parcial dos metassedimentos, gerando o magmatismo granítico peraluminoso. Esta hipótese é corroborada pela ocorrência de paragêneses que atingem a zona da sillimanita nos metapelitos do CMB na região do Ribeirão do Ouro, em Botuverá (Sander 1992).

A intrusão dos granitos Valsungana e Serra dos Macacos é responsável pela formação de rochas cornubianíticas, gerando auréola de contato que podem ser observada nas proximidades dos plútons graníticos nas porções norte e sul da área estudada. Esta auréola mostra zonação metamórfica bem definida nas rochas metapelíticas, com a formação das zonas da biotita, andaluzita, granada, estaurolita, cordierita e silimanita (Fig. 6). Estas paragêneses indicam que o metamorfismo de contato ocorreu sob 
Tabela 3 - Principais paragênese metamórficas dos eventos de metamorfismo regional,de contato e associado a zonas de cisalhamento que afetaram o CMB. A numeração das paragêneses indica a sua localização no mapa da figura 6.

\begin{tabular}{l|l}
\hline \multicolumn{1}{c|}{$\begin{array}{c}\text { Tipo de } \\
\text { metamorfismo }\end{array}$} & \multicolumn{1}{c}{ Paragêneses } \\
\hline REGIONAL & 01) gran-musc-bt-clo-qz-and, 02) clo-musc-qz-carb, 03) qz-musc, 04) bt-musc-qz-carb, 05) gran- \\
OROGÊNICO & $\begin{array}{l}\text { musc-bt-clo-qz, 06) bt-musc-carb-qz, 07) clo-musc-qz, 08) clo-musc-qz, 09) clo-musc-bt-qz, 10) } \\
\text { trem-carb-flog-qz, 11) cord-qz-bt-musc, 12) gran-musc-bt-qz, 13) musc-bt-gran-qz, 14) ep-ab-act, 15) } \\
\text { bt-clo-carb-trem-musc-qz, 16) qz-clo-musc, 17) bt-musc-qz, 18) hb-plag-ep, 19) act-ab-ep-clo }\end{array}$ \\
\hline DE CONTATO & $\begin{array}{l}\text { 01) bt-cord-and-sil, 02) hb-ep-pl, 03) hb-act-pl-ep, 04) ep-diop-hb, 05) flog-gross-(rem-ep-FK-qz, 06) } \\
\text { diop-trem-flog-FK-qz-carb, 07) sil-cord-gran-musc-bt-qz, 08) flog-diop-hb-pl-qz-cumm, 09) qz-ep- } \\
\text { gross-carb-diop-zo-pl, 10) flog-trem-ep, 11) carb-ep-tc-trem-diop, 12) stt-bt-musc-qz, 13) and-cord- }\end{array}$ \\
& $\begin{array}{l}\text { FK-bt-musc-qz, 14) gran-musc-bt-qz, 15) trem-qz-flog-carb, 16) stt-bt-musc-qz, 17) gran-musc-qz, 18) } \\
\text { bt-ep-musc-qz--trem, 19) cord-FK-musc-bt-qz, 20) hb-bt-pl-qz, 21) cian-musc-qz }\end{array}$ \\
\hline DE ZONA DE & 01) qz-FK-bt-ep-musc, 02) qz-bt-clo-ep \\
CISALHAMENTO &
\end{tabular}
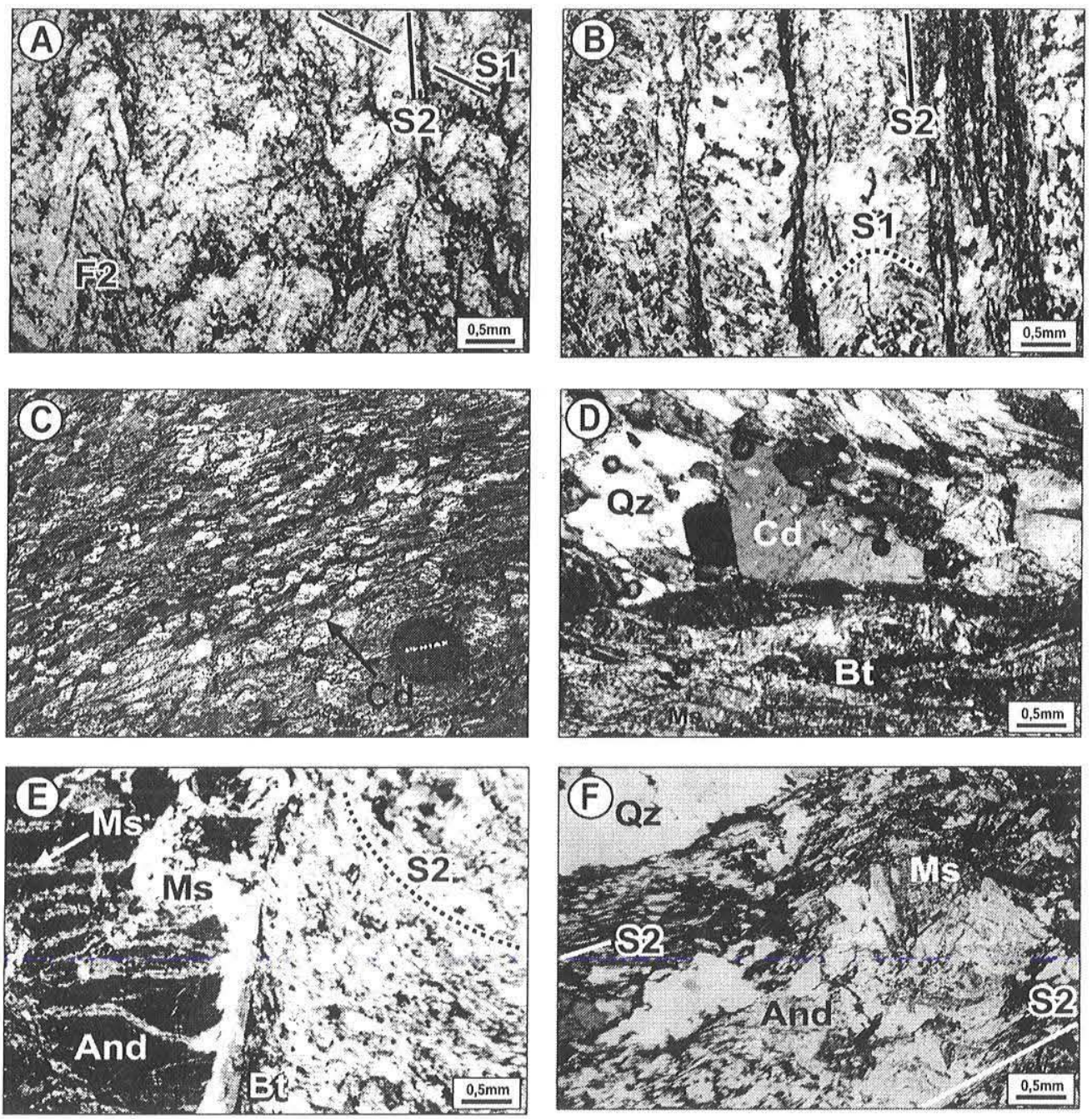

Figura 7 - Principais feições microestruturais associadas ao metamorfismo regional. A) Dobra $F_{2}$ em muscovita-biotita-quartzo xisto ilustrando a relação entre as foliações $S_{1}$ e $S_{2}$, luz natural, $25 X ; B$ ) Clivagem de crenulação com transposição da foliação $S_{1}$ e formação da foliação $S$, em clorita-quartzo-muscovita xisto, luz polarizada, $25 X$; C) Porfiroblastos de cordierita sin- $S_{2}$ em quartzobiotita-cordierita-muscovita xisto (Hotel Savóia, Itapema); D) Cristal de cordierita sin- $S_{2}$ em quartzo-cordierita-biotita-muscovita xisto, luz polarizada, $25 X$ (BR-101, Itapema); E) Porfiroblasto de andaluzita sin-a tardi-S, em andaluzita-quartzo-muscovita xisto. Notar encurvamento da $S$, nas proximidades do porfiroblasto e crescimento de muscovita é biotita pós- $S_{2}$ em fraturas internas e nos limites da andaluzita, luz polarizada, $25 X ; F)$ Porfiroblasto $\sin -S_{2}$ de andaluzita em clorita-quartzo-muscovita xisto. Observar novamente o crescimento de muscovita pós- $S_{2}$ relacionada à intrusão do Granito Valsungana, luz polarizada, $25 X$. 
condições variáveis entre as da fácies albita-epidoto cornubianito e piroxênio cornubianito. Estas transformações geram cornubianitos com texturas porfiroblástica e poiquiloblástica, definidas principalmente por minerais aluminosos. Apesar da preservação comum da estrutura xistosa e/ou bandada, os cornubianitos mostram matriz com textura granoblástica poligonal a interlobada hipidioblástica fina a média (Figs. 8a-f). A existência de evento termal desta natureza torna necessário um pequeno intervalo de tempo entre o pico do metamorfismo regional orogênico e a colocação dos granitos Valsungana e Serra dos Macacos. Durante este período, o soerguimento do cinturão seria responsável pelo resfriamento das rochas metamórficas.

As transformações metamórficas relacionadas às zonas de cisalhamento dúcteis associadas à Zona de Cisalhamento Major Gercino caracterizam-se pela formação de estruturas e texturas miloníticas, preferencialmente desenvolvidas nas rochas metabásicas e granitóides de idade Brasiliana. As condições metamórficas observadas incluem transformações compatíveis com a fácies xistos verdes como a recristalização do quartzo e localmente do $\mathrm{K}$-feldspato, crescimento de epidoto, micas brancas e carbonatos sobre plagioclásio, micas brancas sobre $\mathrm{K}$-feldspato, transformação da biotita ígnea em agregados finos de mica branca, clorita, esfeno e opacos.

CONSIDERAÇÕES FINAIS Na região estudada, o CMB é constituído por 3 subunidades de rochas metassedimentares (clástica, clástico-química e química) e duas subunidades metavulcânicas (básica e magnesiana). A relação composicional e de contato entre os metassedimentos é indicativa de uma seqüência sedimentar pretérita semelhante às encontradas em ambientes plataformais e/ou em bacias intra-cratônicas. A presença no CMB de rochas metabásicas de composição toleítica e alcalina, associadas com rochas vulcânicas ácidas (Sander 1992), é indicativa da existência de magmatismo bimodal característico de ambientes que evoluíram como rifts continentais. A ausência de associações ofiolíticas sugere que o processo de fraturamento provavelmente ocorreu em ambiente intracratônico, sem o desenvolvimento de crosta oceânica.

A formação de associações minerais de baixa pressão, como andaluzita e cordierita, aponta para o elevado gradiente termal nesta região. A explicação para estas condições parece estar relacionada diretamente à presença do magmatismo granítico peraluminoso, que apresenta posicionamento sincrônico à geração da foliação $\mathrm{S}_{2}$. Estas considerações permitem inferir que o elevado gradiente geotérmico encontrado nesta região poderia estar relacionado ao encurtamento rápido da bacia, com o espessamento crustal representando a atuação direta da deformação tangencial. $\mathrm{O}$ rápido espessamento pode ter ocasionado a fusão parcial dos metassedimentos pelíticos do $\mathrm{CMB}$ localizados em zonas mais profundas. A ascensão dos magmas graníticos ocorreu ao longo das estruturas geradas durante a formação da $S_{2}$ como as superfícies axiais dos dobramentos $\mathrm{F}_{2}$ e zonas de cisalhamento dúcteis de baixo ângulo contemporâneas.

As transformações metamórficas regionais relacionadas ao início da colisão são superpostas pelo metamorfismo de contato imposto pelos granitos Valsungana e Serra dos Macacos, cujo posicionamento é controlado por zonas de cisalhamento dúcteis transcorrentes. Temporalmente associados com este metamorfismo de contato, ocorrem transformações metamórficas relacionadas ao desenvolvimento das zonas de cisalhamento dúctil que limitam o CMB. Registros deste tipo de metamorfismo estão preservados pelo desenvolvimento de faixas de rochas miloníticas na porção noroeste e sudeste do Granito Valsungana, nos gnaisses do Complexo Camboriú, bem como, na região de Tijucas, em granitóides correlacionados com os granitos Estaleiro e Zimbros de Bitencourt et al. (1993) (UFRGS, 2000).

Para a compreensão da história evolutiva do CMB ainda são necessários novos levantamentos geológicos e geocronológicos que caracterizem a idade das rochas-fonte dos metassedimentos, idades magmáticas das rochas metavulcânicas e dos metagranitóides, além de estudos que possibilitem a determinação das idades dos eventos de metamorfismo regional.

Agradecimentos Aos Profs. Claiton M.S. Scherer(IG-UFRGS) e Rômulo Machado (IG-USP) pela revisão, discussão e sugestões ao texto final. A todos os alunos e professores do Instituto de Geociências da UFRGS que participaram de alguma forma neste projeto. Aos revisores da RBG pelas sugestões ao manuscrito.

\section{Referências}

Almeida F.F.M. 1967. Origem e Evolução da Plataforma Brasileira. Rio de Janeiro, DNPM-DGM, Boletim 241, 36p.

Basei M.A.S. 1985. O Cinturão Dom Feliciano em Santa Catarina. Tese de Doutorado, Instituto de Geociências, Universidade de São Paulo, 190p.

Basei M.A .S. 1990. O Grupo Brusque: uma evolução monocíclica. In: SBG, Cong. Bras. Geol., 36, Natal, Anais, 6:2649-2657.

Basei M.A.S. \& Teixeira W. 1987. Geocronologia do Pré-Cambriano/ Eopaleozóico de Santa Catarina, In: L.C. Silva \& C.A. Bortoluzzi (Eds.) Texto explicativo para o mapa geológico de estado de Santa Catarina-1:500.000. Florianópolis, DNPM/CPRM, p.91-130.

Bitencourt M.F., Hackspacker P.C., Nardi L.S.V. 1989. A Zona de Cisalhamento Major Gercino - Santa Catarina. In: SBG, SNET, 2, Fortaleza, Atas, p. 214-216.

Bitencourt M.F. \& Nardi L.S.V. 1993. Late- to post-collisional Brasiliano
Magmatism in southernmost Brazil. Anais Acad. Bras. Ciên.,65:3-16.

Bitencourt M.F. \& Nardi L.S.V. 2003. The role of xenoliths and flow segregation in the genesis and evolution of Paleoproterozoic Itapema Granite, a crustally-derived magma of shoshonitic affinity from southern Brazil. Lithos (no prelo).

Borba C. \& Lopes O.F. 1985. O Grupo Brusque e seu embasamento na região de Itapema (SC). In: SBG, Simp. Sul-Brasileiro Geol., II, Atas, Florianópolis, p.24-31.

butcher K. \& Frey M. 1994. Petrogenesis of metamorphic rocks. Complete revision of Winkler's Textbook. 6 Ed., Berlin, SrpingerVerlag, 318 pgs.

Caldasso A.L., Krebs A.S.J., Silva M.A.S., Camozzato E., Ramgrab G.E. 1995. Mapa Geológico 1:50.000 da Folha Brusque, SC, SG22-Z-D-II-I, Programa de Levantamentos Geológicos Básicos, Brasília, CPRM, 243p. 

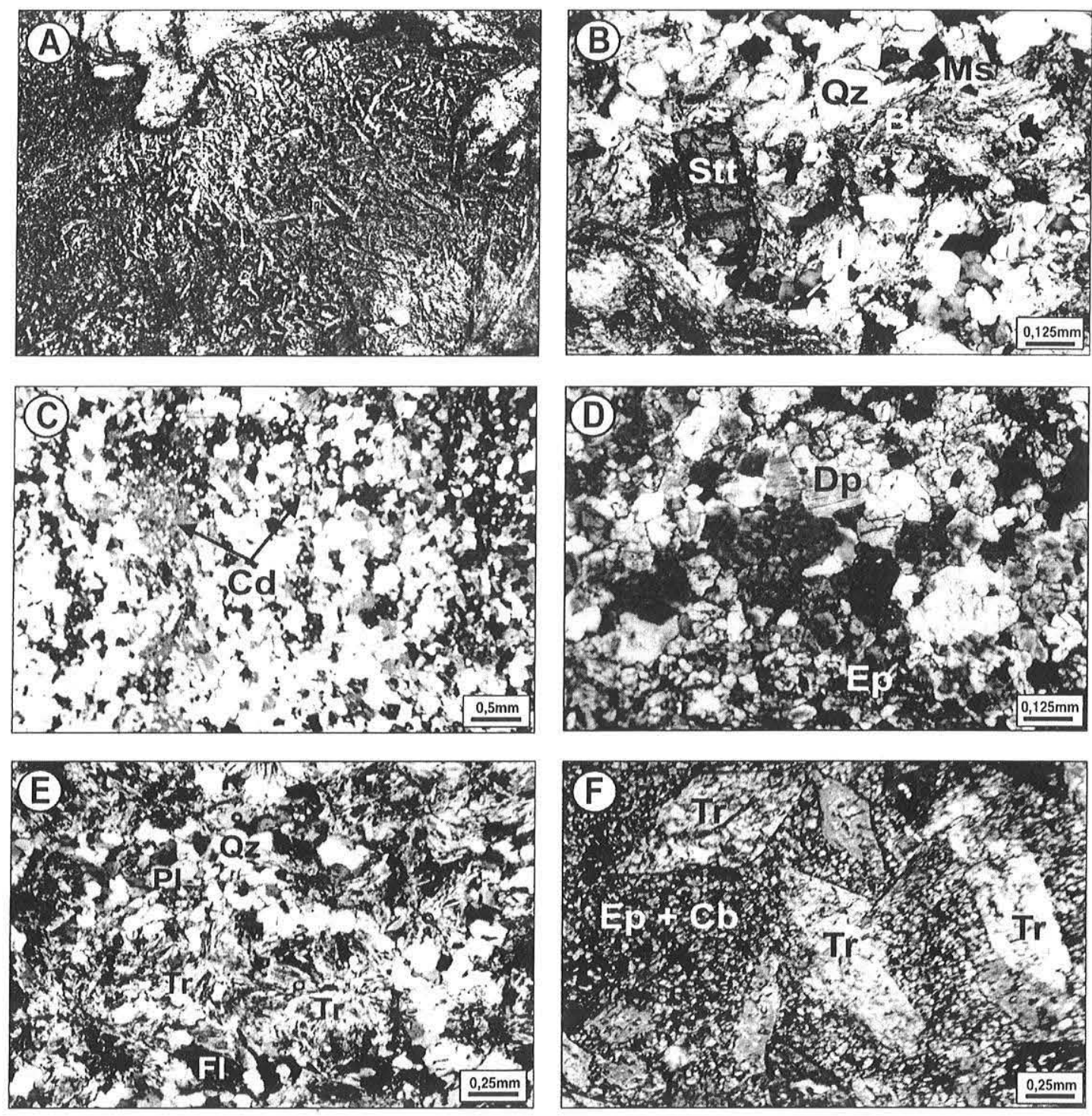

Figura 8 - Texturas e microestruturas relacionadas ao metamorfismo de contato. A) Quartzo-muscovita-cianita cornubianito com desenvolvimento acentuado de porfiroblastos de cianita pós- $S$, sem orientação preferencial; $B$ ) Porfiroblasto idiomórfico de estaurolita sobre relictos da foliação $S_{2}$ em muscovita-biotita-quartzo xisto. Observar o crescimento sem orientação preferencial de palhetas de muscovita e biotita; luz polarizada, IOX; C) Porfiroblastos de cordierita crescendo sobre o acamadamento composicional em muscovita-cordierita-quartzo cornubianito. Textura poiquiloblástica definida por inúmeras inclusões de biotita e quartzo; luz polarizada, 25X; D) Tremolita-plagioclásio-epidoto-diopsídio cornubianito com textura granoblástica poligonal seriada; luz polarizada, 50X; E) Textura acicular definida por agregados fibro-radiados de tremolita e flogopita em flogopita-muscovitatremolita-quartzo cornubianito; luz polarizada, 50X; F) Porfiroblastos idiomórficos de tremolita em carbonato-epidoto-tremolita cornubianito; luz polarizada, 50X.

Carvalho P.F. \& Pinto E.A. 1938. Reconhecimento geológico do estado de Santa Catarina, Rio de Janeiro, DNPM/DGM, Boletim 32, 30p.

Chemale Jr., F., Hartmann L.A., Silva L.C. 1995. Stratigraphy and tectonism of the Brasiliano Cycle in southern Brazil. Communication of Geological Survey Namibia., 10:151-166.

Fragoso Cesar A.R.S. 1980. O Craton do Rio de La Plata e o Cinturão Dom Feliciano no Escudo Uruguaio-Sul-Rio-Grandense. In: SBG, Cong. Bras. Geol., 31, Anais, Camboriú, v.5: 2879-2892.

Hartmann L.A. \& Fernandes L.A.D. 2000a. Crustal evolution of southern Brazil: Juvenile Accretion and shear zones. (L.A. Hartmann, Chapter 1 - Precambrian evolution of southern Brazil, p. 1-26; and L.A.D. Fernandes, Chapter 2 -Strike-slip shear zones, p. 27-50). In: IUGS, Post-Congress Field Trip. $31^{\text {st International }}$ Geological Congress, Rio de Janeiro, Brazil, Field Trip Aft 02, $50 \mathrm{p}$.

Hartmann L.A., Leite J.A.D., Silva L.C., Remus M.V.D., McNaughton N.J., Groves D.I., Fletcher I.R., Santos J.O.S., Vasconcellos M.A.Z. 2000b. Advances in SHRIMP geochronology and their impact on understanding the tectonic and metallogenic evolution of southern 
Brazil. Austral. J. Earth Sci., 47: 829-844.

Hartmann L.A., Bitencourt M.F, Santos J.O.S., McNaughton N.J., Rivera, C.B., Betiollo, L. 2003. Prolonged Paleoproterozoic magmatic participation in the Neoproterozoic Dom Feliciano Belt, Santa Catarina, Brazil, based on zircon U-Pb SHRIMP geochronology. J. Sou. Am. Earth Sci. (no prelo).

Hasui Y., Carneiro C.D.R., Coimbra A.M. 1975. The Ribeira Folded Belt. Rev. Bras. Geoc., 5:257-266.

IUGS - International Subcomission on Stratigraphic Classification (ISSC). 1994. International Stratigraphic Guide - a guide to stratigraphic classification, terminology and procedure, second edition, (Amos Salvador ed.), John Wiley and Sons, New York, 214p.

Mantovani M.S., Hawkesworth C.J., Basei M.A.S. 1987. Nd and Pb isotope studies bearing on the crustal evolution of southeastern Brazil. Rev. bras. Geoc., 17:263-268.

Mônaco O.A., Zir Filho J.A., Valentini N. 1974. Carta Geológica do Brasil ao Milionésimo, Folha Assuncion-SG-21 e Folha Curitiba, $S G$-22. Brasília, DNPM, 83p.

Philipp R.P., Mallmann G., Prado M., Silva M.M.A., Souza E.R., Wild F., Arend S., Liz J.D., Duarte L.C., Oliveira A.S. 2001a. Caracterização litológica e condições metamórficas do Complexo Metamórfico Brusque na região de Camboriú-Tijucas, SC. In: SBG, SNET, 8, Intern. Symp. Tectonics of Brazilian Geol. Soc., 2, Boletim de Resumos Expandidos, Recife, SBG, p.93-97.

Philipp R.P., Wild F., Duarte L.C., Oliveira A.S., Arend S., Rivera C.B., Samberg E., Morales L.F.G., Mallmann G. 200 lb. Caracterização litológica, estrutural e condições metamórficas do Complexo Camboriú, Itapema, SC. In: SBG, SNET, 8, Intern. Symp. on Tectonics of Brazilian Geol. Soc., 2, Resumos Expandidos, Recife, p. 103-105.

Philipp R.P., Mallmann G., Bitencourt, M.F., Oliveira A.S., Souza E.R. 2001 c. Feições estruturais e evolução metamórfica da porção leste do Complexo Metamórfico Brusque, sul do Brasil. In: Congr. LatinoAmericano, 11, Congr. Uruguaio de Geol., 3, Boletim de Resumos Expandidos, Montevidéo, v.1, p.7-11.

Sander A. 1992. Petrologia e litoquímica de uma parcela da sequiência vulcanosedimentar do Complexo Metamórfico Brusque na região do Ribeirão do Ouro, SC. Dissertação de Mestrado, Instituto de Geociências, Universidade Federal do Rio Grande do Sul, 167p.

Schulz Jr. A. \& Albuquerque L.F.F. 1969. Geologia da quadrícula Rio do Sul, Santa Catarina, BRASIL. Porto Alegre, DNPM, 109 p. (inédito).
Silva L.C. 1983a. O Complexo Metamórfico Brusque e a Sequiência Vulcano-sedimentar Rio Itajaí-Mirim, (SC): uma revisão. In: SBG, Simp. Sul-Brasileiro Geol., I, Atas, Porto Alegre, p.253-265.

Silva L.C. 1983b. Basalto variolítico com matriz ultramáfica quench. Primeiras evidências de derrames komatíticos (?) na Sequiência Vulcano-sedimentar Rio Itajaí-Mirim (SC). In: SBG, Simp. SulBrasileiro Geol., I, Atas, Porto Alegre, p.266-272.

Silva L.C. 1991. O Cinturão Metavulcanossedimentar Brusque e a evolução policíclica das faixas dobradas Proterozóicas no sul do Brasil: uma revisão. Rev. Bras. Geoc., 21:60-73.

Silva L.C., Trainini D.R., Hartmann L.A. 1978. Relações entre metamorfismo e deformação no Grupo Brusque, SC. In: SBG, Congr. Bras. Geol., 30, Anais, Recife, 3:1336-1349.

Silva L.C., Dias A.A., Hartmann L.A., Krebs A.S.J., Silva M.A.S. 1980. História metamórfica do Grupo Brusque-SC. Análise comparativa entre as regiões do Russo e da Catinga. In: SBG, Congr. Bras. Geol., 31, Anais, Balneário Camboriú, 5: 2982-2995.

Silva L.C. \& Dias A.A. 1981. Projeto Timbó-Barra Velha, SC, BRASIL. Porto Alegre, DNPM- CPRM, 282p. (inédito).

Silva L.C., Oliveira J.M.P., Aumond J. J., Lopes R.M.M., Eipper J., Ferro G. 1985. Caracterização petrográfica da Seqüência Metavulcano-Sedimentar Rio do Oliveira (Cinturão Itajaí-Mirim). In: SBG, Simp. Sul-Brasileiro Geol., I, Atas, Porto Alegre, p.11-23.

Silva L.C., McNaughton, N.J., Santos, J.O.S. 2002. Datações U-Pb SHRIMP do vulcanismo félsico na Bacia Brusque, Orógeno Pelotas, SC. In: SBG, Congr. Bras. Geol., 41, Anais, João Pessoa, p.510.

Takeda F.K. 1958. Esboço Geológico de Santa Catarina. Atlas Geográfico de Santa Catarina, Florianópolis, IBGE, 6 .

Trainini D.R., Dias A.A., Krebs A.S.J., Souza E.C., Capeletti I., Toniolo J.A., Silva L.C., Silva M.A.S. 1978. Projeto Vidal Ramos-Biguaçu, $S C, B R A S I I .$, Porto Alegre, DNPM/CPRM, 303p. (inédito).

UFRGS. 2000. Projeto Camboriú - Mapa Geológico 1:25.000 das folhas Camboriú e parte sul da Folha Itajaí. Trabalho de Graduação, Instituto de Geociências, Universidade Federal do Rio Grande do Sul, (inédito).

Manuscrito A-1274

Recebido em 16 de novembro de 2001

Revisão dos autores em 04 de novembro de 2003 Revisão aceita em 20 de novembro de 2003 